\title{
The Effect of Inquiry-based Learning Method on Students' Academic Achievement in Science Course
}

\author{
Ali Abdi \\ Department of Educational Sciences Payame noor University , PO BOX 19395-3697 Tehran, Iran \\ *Corresponding Author: raziali88@gmail.com
}

Copyright (C) 2014 Horizon Research Publishing All rights reserved.

\begin{abstract}
The purpose of this study was to investigate the effects of inquiry-based learning method on students' academic achievement in sciences lesson. A total of 40 fifth grade students from two different classes were involved in the study. They were selected through purposive sampling method. The group which was assigned as experimental group was instructed through inquiry-based learning method whereas the other group was traditionally instructed. This experimental study lasted eight weeks. To determine the effectiveness of inquiry-based learning method over traditional instruction, an achievement test about sciences which consisted of 30 items was administered as pre-test and post-test to students both in the experimental and control groups. For the statistical analysis, Analysis of Covariance (ANCOVA) was used. The results showed that students who were instructed through inquiry-based learning were achieved higher score than the ones which were instructed through the traditional method.
\end{abstract}

Keywords Inquiry-Based Learning Method, Traditional Method, Sciences Course

\section{Introduction}

In the current information and technology age, when scientific information increases day by day technological innovations advance rapidly, it is clearly seen that the education of science and technology plays a key role for the future of the societies and the effects of science and technology are seen overtly in every aspect of our lives (karamustafaoglu, 2010). ). Rubba and Andersen (1978), Hurd (1970) and Klopfer (1971) indicate that the major goal of science education should be developing students "scientific literacy". Since the goal of science education is related to very important questions which are "why teach science to who teach science and at what level", there is a relationship between the method of instruction and the attainment of objectives (Baez, 1971). Among these different kinds of methodologies, inquiry method has an important place.

The inquiry-based teaching approach is supported on knowledge about the learning process that has emerged from research (Bransford, Brown, \& Cocking, 2000). In inquiry-based science education, children become engaged in many of the activities and thinking processes that scientists use to produce new knowledge. Science educators encourage teachers to replace traditional teacher-centered instructional practices, such as emphasis on textbooks, lectures, and scientific facts, with inquiry-oriented approaches that (a) engage student interest in science, (b) provide opportunities for students to use appropriate laboratory techniques to collect evidence, (c) require students to solve problems using logic and evidence, (d) encourage students to conduct further study to develop more elaborate explanations, and (e) emphasize the importance of writing scientific explanations on the basis of evidence(secker,2002). Sandoval \& Reiser(2004) pointed out in order to build the inquiry-based classroom environment must construct a community of practice like the scientists work. In authentic inquiry-based activities, the students take action as scientists did, experiencing the process of knowing and the justification of knowledge.

In contrast, the traditional classroom often looks like a one-person show with a largely uninvolved learner. Traditional classes are usually dominated by direct and unilateral instruction. Traditional approach followers assume that there is a fixed body of knowledge that the student must come to know. Students are expected to blindly accept the information they are given without questioning the instructor (Stofflett, 1998). The teacher seeks to transfer thoughts and meanings to the passive student leaving little room for student-initiated questions, independent thought or interaction between students (VAST, 1998). Even the in activities based subjects, although activities are done in a group but do not encourage discussion or exploration of the concepts involved. This tends to overlook the critical thinking and unifying concepts essential to true science literacy and appreciation (Yore, 2001). This teacher-centered method of teaching also assumes that all students have the same level of background knowledge in the subject matter 
and are able to absorb the material at the same pace (Lord, 1999).

There are different forms of inquiry learning(Bulbul,2010). In structured inquiry the teacher provides the input for the student with a problem to investigate along with the procedures and materials. This type of inquiry learning is used to teach a specific concept, fact or skill and leads the way to open inquiry where the student formulates his own problem to investigate. An example of a structured inquiry learning approach is the Learning Inquiry Cycle Model, based on Piagets theory of cognitive learning (Bevevino, Dengel, \& Adams, 1999). The learning cycle model is a teaching procedure consistent with the inquiry nature of science and with the way children naturally learn (Cavallo \& Laubach, 2001). Many versions of the learning cycle appear in science curricula with phases ranging in number from $4 \mathrm{E}$ to $5 \mathrm{E}$ to $7 \mathrm{E}$. Regardless of the quantity of phases, every learning cycle has at its core the same purpose (Settlage, 2000). In this study, $5 \mathrm{E}$ learning cycle instruction model by Bybee et al., (2006) was used. It requires the instruction of five discrete elements: (a) Engagement: The teacher or a curriculum task accesses the learners' prior knowledge and helps them become engaged in a new concept through the use of short activities that promote curiosity and elicit prior knowledge. (b)Exploration: Exploration experiences provide students with a common base of activities within which current concepts (particularly misconceptions), processes, and skills are identified and conceptual change is facilitated. (c)Explanation: The explanation phase focuses students' attention on a particular aspect of their engagement and exploration experiences and provides opportunities to demonstrate their conceptual understanding, process skills, or behaviors. This phase also provides opportunities for teachers to directly introduce a concept, process, or skill. (d)Elaboration: After receiving explanations about main ideas and terms for their learning tasks, it is important to involve the students in further experiences that extend, or elaborate, the concepts, processes, or skills. This elaboration phase facilitates the transfer of concepts to closely related but new situations. In some cases, students may still have misconceptions, or they may only understand a concept in terms of the exploratory experience. (e)Evaluation: This is the important opportunity for students to use the skills they have acquired and evaluate their understanding. In addition, the students should receive feedback on the adequacy of their explanations. Informal evaluation can occur at the beginning and throughout the $5 \mathrm{E}$ sequence. The teacher can complete a formal evaluation after the elaboration phase. This is the phase in which teachers administer assessments to determine each students level of understanding (Bybee et al., 2006).So, the purpose of this study is to examine the effects of inquiry-based instruction supported $5 \mathrm{E}$ learning cycle on 5 grade students' achievements as a school subject. This study, seeks the answer to the following question: Is teaching science with inquiry-based instruction supported $5 \mathrm{E}$ learning cycle more effective than traditional science teaching methods?

\section{Hypothesis}

There will be no significant difference in the mean gain achievement scores of the learners in controlled group and experimental group.

\section{Methodology}

\section{A. Design of the Study}

This research was a quasi-experimental study with non-equivalent groups, which includes pre and post-test design with the control group. Since the classes were formed at the beginning of the semester by school administration, it was not possible to assign students randomly to both experimental and control groups. But the classes were randomly assigned as control and experimental group.

The experiment design pattern is shown in Figure 1. In the pattern below, $\mathrm{O} 1$ is experiment group while $\mathrm{O} 2$ is control group. " $\mathrm{X}$ " represents treatment i.e. Inquiry-Based teaching approach (learning cycle model).

\begin{tabular}{cccc}
\hline Groups & Pre-test & $\begin{array}{c}\text { Experiment } \\
\text { treatment }\end{array}$ & Post test \\
\hline $\begin{array}{c}\text { Experimental } \\
\text { group }\end{array}$ & $\mathrm{O} 1$ & $\mathrm{X}$ & $\mathrm{O} 1$ \\
Control group & $\mathrm{O} 2$ & - & $\mathrm{O} 2$ \\
\hline
\end{tabular}

Figure 1. The experiment design pattern

\section{B. Sampling}

The study was conducted with 20 experimental and 20 control group girl students at 5 th grade in primary schools in Kermanshah, Iran. The selection of the school had been done through purposive sampling method. Classes were randomly assigned as the "control" and "experimental" groups. In order to ensure the equivalence at experimental and control groups, students' previous year graduate points of achievement (GPA), intelligence fields, the number of students at the groups and pretest results were taken into account. It was found that experimental group was statistically equal to control group.

\section{Instrument}

Academic Achievement Test was given to both groups as pre-test and post-test. The test included 30 multiple-choice items to measure the students' academic achievement. Each question had one correct answer and three 'distracters'. This was a teacher made test and it has been based on the table of specification. This table was organized for 3 chapters of the course "sciences education". The content validity of the study was examined by two sciences teachers, one researcher and one university professor. The internal consistency reliability (Cronbach's alpha) of this test was found to be 0.75 . 


\section{Procedures}

The researcher used the following two treatments in the present study:

a Taught by using 5E learning cycle (experimental group)

b Taught by using traditional method (control group)

Both groups were instructed by the same sciences teacher. Before the implementation of treatment the teacher was informed about the purpose of the study and 5E learning cycle based instruction.

In order to check the implementation of both treatments in control and experimental groups classroom observations were carried out. In the control group, implementation of instruction based on traditional method, in the experimental group implementation of instruction based on 5E learning cycle model were analyzed carefully. During the process of observation, the interaction between teacher-students and students-students; participation and contribution of students into learning environment; behaviour and attitude of students and teacher as well as the physical conditions and material availability of the classroom were observed. Before observation of the real implementation process, researcher visited the classrooms 2 times, sat silently at the back and observed classroom.

Student in the experimental group were instructed with inquiry-based instruction supported $5 \mathrm{E}$ learning cycle. In the instruction based on $5 \mathrm{E}$ learning cycle method, teaching and learning activities and lesson plans were designed to maximize students active involvement in the learning process. The topics included in the lesson plans were about the three units of fifth-grade sciences book; they included: hidden strangles (microbes, viruses, diseases, body's defenses ways, helping the defense of the body, and vaccines); nervous system and sense organs; and human and environment.

Activities and lesson plans were implemented by considering stages of $5 \mathrm{E}$ learning cycle model.

In the engagement phase, teacher tried to increase students attention, get them interested and ready to learn. So that students had opportunities to make some connections between prior knowledge and present learning experiences. So that their thinking was organized toward learning out comes. Students had previous knowledge about the concepts like microbes, viruses, diseases and vaccines. An interesting image symbolizing the body's defenses system was presented to the students. In addition, a story about the relationship among the microbes, viruses and body's defenses system was read. In the exploration phase, intention was to create learning environments for students so that they could observe scientific processes, record data, isolate variables, design and plan experiments, create graphs, interpret results, develop hypotheses, and organize their findings. Teacher only provided questions, suggested approaches, gave feedbacks, and assessed understandings. Microbe structure was examined under the microscope in the following class. Activities used in the explanation phase helped students demonstrate their understanding of related concepts. Teacher guided students toward coherent and consistent generalizations, helps students with distinct scientific vocabulary, and provided questions that help students use this vocabulary to explain the results of their explorations. Activities used in elaboration phase, provided an opportunity for students to apply their knowledge to new domains, which may include raising new questions and hypotheses to explore. A research task about the importance of vaccines was given in elaboration stage. With the activities used in the evaluation phase students had opportunity to assess their understanding and abilities. The activities in evaluation phases were also used by teacher for both formative and summative evaluations of student learning.

In the control group, a teacher directed strategy representing the traditional approach was used. The teacher used direct teaching and question and answer methods to teach related topics and basic concepts. Basic explanations and question and answer methods suited the traditional teaching approach where students are completely passive, were used while teaching the hidden strangles unit. Teaching strategies consisted of the teacher's explanations and textbooks. In this group, the teacher provided instruction through lecture and discussion methods to teach the concepts. The teacher structured the entire class as a unit, wrote notes on the chalkboard about the definition of concepts, and passed out worksheets for students to complete. The primary underlying principle was that knowledge takes the form of information that is transmitted to students. After the teacher's explanations, some concepts were discussed, prompted by teacher-directed questions. Worksheets were developed specifically for each lesson. These required written responses and reinforced the concepts presented in the classroom sessions. They were collected and corrected by the researcher. Each lesson typically consisted of the teacher presenting the correct way to solve problems. The majority of instructional time was devoted to instruction and engaging in discussion stemming from the teacher's explanation and questions.

Both traditional and inquiry classes used the same textbook and handouts. The study took 8 weeks, six weeks for the instruction, two weeks for the application of the preand the post-tests.

\section{E. Analysis of Data}

In the present study, the researcher has used different types of statistical techniques. They were Mean, Standard deviation and "one-way ANCOVA" test.

\section{Research Findings}

Table 1 indicates that experimental group performed better than the control group as shown by the values of means and standard deviations but one cannot say whether these differences observed is significant or not. 
Table 1. Means, Standard Deviations and Std. Error Mean of the Experimental and Control Groups for Pretests and posttest scores in academic achievement test

\begin{tabular}{cccccc}
\hline variable & group & $\mathrm{N}$ & Mean & Std. Deviation & $\begin{array}{c}\text { Std. Error } \\
\text { Mean }\end{array}$ \\
\hline \multirow{2}{*}{ Pre-test } & experimental & 20 & 3.15 & 1.461 & .327 \\
& control & 20 & 2.95 & 1.538 & .344 \\
Post-test & experimental & 20 & 7.30 & .979 & .219 \\
& control & 20 & 6.35 & 1.226 & .274 \\
\hline
\end{tabular}

Table 2. ANCOVA analysis for the differences in post-test mean scores between experimental and control groups in academic achievement test

\begin{tabular}{cccccc}
\hline $\begin{array}{c}\text { Sour } \\
\text { ce }\end{array}$ & $\begin{array}{c}\text { Sum of } \\
\text { Squares }\end{array}$ & df & $\begin{array}{c}\text { Mean } \\
\text { Square }\end{array}$ & F & $\begin{array}{c}\text { Si } \\
\text { g. }\end{array}$ \\
\hline pre & 2.327 & 1 & 2.327 & 2.0 & .16 \\
& & & & 56 & 0 \\
Grou & 5.796 & 1 & 5.796 & 21 & .03 \\
p & 40.743 & 36 & & & 0 \\
Error & 1919.000 & 40 & & & \\
Total & & & & \\
\hline
\end{tabular}

In order to investigate a research hypothesis, we used ANCOVA analysis. In the table 2 data on ANCOVA analysis for the differences in post-test scores between experimental and control groups in academic achievement test.

Table 2 indicates that the (F) value was (5.121) and it was significant value at the level (.030). This means that there is a significant difference in the means score of students taught sciences education using inquiry-based instruction supported 5E learning cycle and those taught using traditional approach.

\section{Conclusion}

Based on the findings obtained in the study, it can be said that there is a significant difference between the achievement levels of the students who have been educated by inquiry-based instruction supported 5E learning method and the students who have been educated by the traditional teaching methods. The students who have been educated by inquiry-based instruction supported 5E learning cycle method have become more successful than the students who have been educated by the traditional teaching methods. This study offers results that support work previously performed by other researchers (Adams, Bevevino \& Dengel, 1999; Sungur, Tekkaya \& Geban, 2001; Lord, 1999; Marek, Eubanks \& Gallaher, 1990; Seyhan \& Morgil, 2007; Anderson, 2002, Cardak, Dikmenli and Saritas,2008).

Seyhan \& Morgil (2007) compared two classes taught by traditional methods with two classes taught using the $5 \mathrm{E}$ instructional model method. The study indicated that the experimental groups had much greater understanding of the information covered especially on questions that required interpretation.
Pandey et al. (2011) and Asimge Akpulluku et al (2011) concluded that inquiry training model have statistically significant effect over conventional teaching method on academic achievement of students.

Therefore, Classroom teachers should consider how to prepare learning environments in which students will be active in accordance with their characteristics and then present these environments to students. Creating techniques based on the $5 \mathrm{E}$ instructional model on various subjects will attach a higher degree of importance on the $5 \mathrm{E}$ instructional model. In addition, the education of trainee teachers will benefit from these methods.

\section{REFRENCES}

[1] Akpulluku. A, and Gunay.F.Y (2011)“"The Effect of Inquiry Based Learning Environment In Science And Technology Course On The Students' Academic Achievements," Western Anatolia Journal of Educational Sciences, Dokuz Eylul University Institute, Izmir, Turkey, ISSN 1308-8971,.

[2] Anderson, R. (1997). The research on teaching as inquiry. Paper presented for the Center for Science, Mathematics and Engineering Education. National Research Council, Washington D.C.

[3] Anderson, R. (2002). Reforming Science Teaching: What research says about inquiry. Journal of Science Teacher Education, 13, 1-2.

[4] Baez, A. (1971). "Aims, Contents and Methodology of Science Teaching”, in Science and Education in Developing States, edited by Gillon, H., Draeger Publishers, New York.

[5] Bevevino, M., Dengel, J. and Adams, K. (1999), Constructivist Theory in the Classroom, Constructivist Theory In the Classroom 
[6] Bransford, J.D., A.L. Brown, and R.R. Cocking, eds. (2000). How People Learn. Washington, D.C.: National Academy Press.

[7] Bulbul, y.(2010).Effects of 7E learning cycle model accompanied with computer animations on Understanding of diffusion and osmosis concepts. Middle East Technical University.

[8] Bybee, R., Taylor J., Gardner A., Scotter, P., Powell, J., Westbrook, A., \& Landes, N., (2006). The BSCS 5E Instructional Model: Origins, Effectives, and Applications.Executive Summary, BSCS, Colorado Springs, CO.

[9] Carak,O, Dikmenli. M, \& Saritas, O.(2008)Effect of 5E instructional model in student success in primary school 6th year circulatory system topic. Asia-Pacific Forum on Science Learning and Teaching, Volume 9, Issue 2, Article 10, p.2

[10] Cavallo, A.M.L. \& Laubach, T.A. (2001). Students' Science Perceptions and Enrollment Decisions in Differing Learning Cycle Classrooms. Journal of Research in Science Teaching, 38(9), 1029-1062..

[11] Hurd, P.D.H. (1970). Scientific enlightement for an age of science. The Science Teacher, January, 13-15,

[12] Karamustafaoglu,s.(2010)Evaluating the Science Activities Based On Multiple Intelligence Theory. Journal of TURKISH SCIENCE EDUCATION Volume 7, Issue 1, March

[13] Klopfer, L.E. (1971). Evaluation of learnings in science, In B.S. Bloom, J.T. Hastings, and G.F.Madaus. (Eds.), Handbook on Formative Summative Evaluation of Student Learning. New York, McGraw-Hill, 559-642.

[14] Lord, Thomas R. 1999. A Comparison Between Traditional and Constructivist Teaching in Environmental Science. Journal of Environmental Education. Vol. 30, No. 3:22-28.

[15] Marek, E.A., Eubanks, C. \& Gallaher, T. (1990). Teachers' understanding and the use of the learning cycle. Journal of Research in Science Teaching, 27(9), 821-834.
[16] Pandey. A, Nanda. G. K. and Ranjan. V(2011) "Effectiveness of Inquiry Training Model over Conventional Teaching Method on Academic Achievement of Science Students in India," Journal of Innovative Research in Education, vol.1(1), pp. 7-20, 2011.

[17] Rubba, P.A. and Andersen, H.O.,( 1978) Development of an instrument to assess secondary school students' understanding of the nature of scientific knowledge. Science Education, 62(4): 449-458,.

[18] Sandoval, W. A., \& Reiser, B. J.(2004). Explanation-driven inquiry: Integrating conceptual and epistemic scaffolds for scientific inquiry. Science Education, 88, 342-375.

[19] Secker.v.c(2002)Effects of Inquiry-Based Teacher Practices on Science Excellence and Equity .The Journal of Educational ResearchJanuary/February 2002 [Vol. 95(No. 3)]

[20] Seyhan, H. \& Morgil, I. (2007). The effect of 5E learning model on teaching of asid- base topic in chemistry education. Jounal of Science Education, 8(2), 120-123.

[21] Stofflett, Rene T. (1998). Putting Constructivist Teaching into Practice in Undergraduate Introductory Science. Electronic Journal of Science Education, Vol. 3, No. 2.

[22] Sungur, S., Tekkaya, C. \& Geban, Ö. (2001). The contribution of conceptual change texts accompanied by concept mapping to students' understanding of human circulatory system. School Science and Mathematics, 101, 91-101.

[23] Virginia Association of Science Teachers (VAST), (1998). What is constructivism and what does it mean for science educators? Current Topics in Science Education..

[24] Watson, J.R., Swain, F.R.L., \& McRobbie, C. (2004). Students' discussions in practical scientific inquiries. International Journal of Science Education, 26(1),25-45.

[25] Yore, Larry D. 2001. What is Meant by Constructivist Science Teaching and Will the Science Education Community Stay the Course for Meaningful Reform? Electronic Journal of Science Education, Vol. 5, No. 4. 